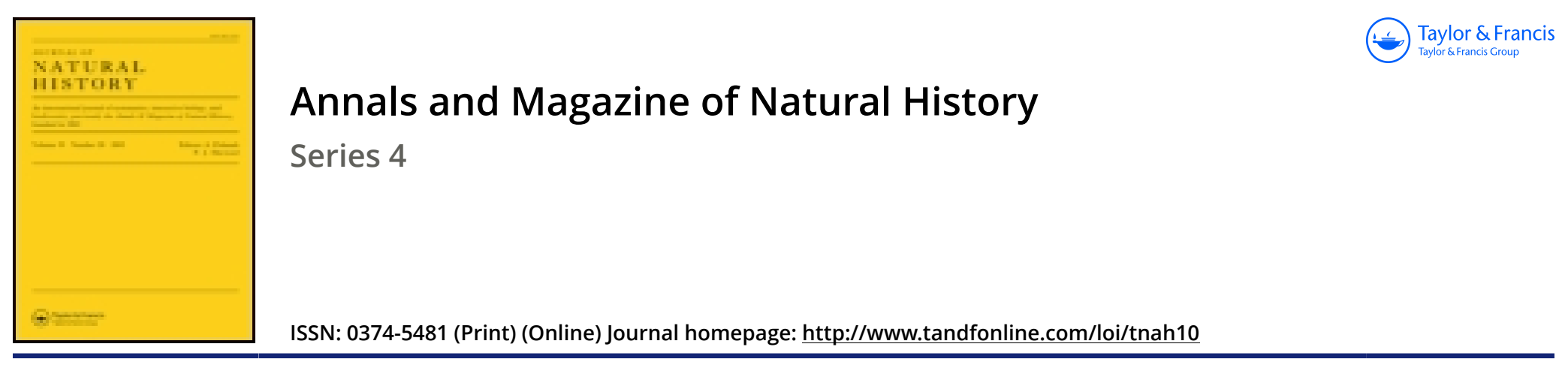

\title{
XXVIII.-Hermaphroditism in the Parasitic Isopoda. Further remarks on Mr. Bullar's papers on the above subject
}

\section{H.N. Moseley}

To cite this article: H.N. Moseley (1877) XXVIII._-Hermaphroditism in the Parasitic Isopoda.

Further remarks on Mr. Bullar's papers on the above subject, Annals and Magazine of Natural History, 19:112, 310-311, DOI: 10.1080/00222937708682147

To link to this article: http://dx.doi.org/10.1080/00222937708682147

曲 Published online: 13 Oct 2009.

Submit your article to this journal $\pi$

Џll Article views: 3

Q View related articles $\sqsubset$ 
Athalochroa Ashmoliana, Westwood.

Vates Ashmolianus, Westwood, Ann.\& Mag. Nat. Hist. vol. viii. p. 272 ; Arcana Entomol. 1843, vol. ii. p. 52 (note †).

"Fuscus, capitis vertice rotundato, antennis gracillimis, prothorace

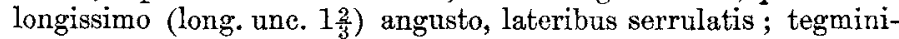
bus et alis abdomen haud tegentibus, illis pallidis griseo et fusco parum variis nubecula fusca basin versus, venisque nigro strigatis ; alis hyalinis, costa maculisque nubeculaque basin versus brunneis ; cercis analibus latis foliaceis ; pedibus 4 posticis brevibus, femoribus fere ad apicem 3 -foliatis tibiisque ante medium supra parum foliatis. Long. corporis unc. $4 \frac{1}{3}$. Habitat in India orientali."

The following are the measurements of a dried specimen of the male and of a female preserved in alcohol :-

Total length, $\delta 100, q 115$ millims. ; length of prothorax o 33 , o 40-of which the neck is respectively, of $7 \cdot 6$ and $q$ 9.5 ; width of prothorax at supracoxal dilatation, $\delta 4.5$, o $5 \cdot 6$ - at hinder extremity, $\delta 3 \cdot 6$, $q 4.5$; length of abdomen, $\delta 46, q 52$; width of abdomen at middle, $\delta 3 \cdot 5$, q 5 ; length of tegmina, $\pi 45$, +55 ; width of tegmina across middle, $\delta 9$, o 11 ; length of wings, $\delta 42$, +52 ; of fore coxa, $\delta 15$, q 16.5 ; of femur, $\delta 16.5$, 19.75 ; of tibia (from base to insertion of tarsus), $\sigma^{*} 12$, $q 15$; of immediate femur, $\delta 125$, Q 15.5 ; of tibia, o $12 \cdot 5$, ㅇ 15.5 ; of posterior femur, o 15 , $q 19$; of tibia, 15 , $q 19$; of antennæ, 023 , +18 ; of cerci, $\delta 7 \cdot 5$, ㅇ $8 \cdot 5$; width of cerci, of $2,+2 \cdot 6$.

$H a b$. I am indebted for the female of this fine and remarkable insect to my friend Dr. T. R. Lewis, who captured it in the garden attached to the General Hospital in Calcutta; for the male to Mr. C. V. Marshall, by whom it was taken at Berhampur, near Murshidabád, in Lower Bengal.

XXVIII.-Hermaphroditism in the Parasitic Isopoda. Further Remarks on Mr. Bullar's Papers on the above subject. By H. N. Moseley, Fellow of Exeter College, Oxford.

Mr. Bullar does not appear to strengthen his position materially in his reply to my remarks on his paper on the "Generative Organs of the Parasitic Isopoda" (Journ. of Anat. and Physiol., Oct, 1876, p. 118), in the March number of this Journal.

There seems to be no proof that the small masses of tissue figured by Mr. Bullar as testes are in reality organs of such 
nature ; and it is on this point that the whole question of hermaphroditism or unisexuality must be decided. The testes of Asellus aquaticus, on the external resemblance of which to the supposed testes of his parasitic forms $\mathrm{Mr}$. Bullar relies, have an unusually marked and characteristic histological structure. They contain very large mother cells, in which the long filaments of the developing spermatozoa are coiled in bundles. Although Mr. Bullar has examined his Isopods in all stages, and in the fresh as well as prepared conditions, he gives no evidence as to any such structure in the supposed testes of these animals : he merely says that the organs "are filled with a cellular biastema, from which doubtless the spermatozoa are developed."

It seems to me that the absence of positive evidence that the spermatozoa are thus developed constitutes a serious flaw in the chain of evidence by which Mr. Bullar seeks to establish his conclusion. Testis-tissue is not by any means a difficult object for histological observation ; and since it is evident, from the detailed description which Mr. Bullar gives of the minute structure of the ovaries in his Isopods, that he has carefully studied the histology of their generative organs, he could hardly have overlooked definite testis-structure had such existed in the objects which he terms testes.

I cannot but consider that it will be more prudent to await further evidence before accepting as demonstrated the fact that the members of the subfamily of the Cymothoinæ alone amongst Isopods are hermaphrodite-although, were this conclusion confirmed, it would be of great interest, and might be considered as paralleled by such instances as the hermaphroditism of the Serranidæ amongst fishes.

XXIX.-Descriptions of three Homopterous Insects in the Collection of the British Museum. By Arthur Gardiner ButLer, F.L.S.

Platypleura, Amyot \& Serville.

Platypleura nicobarica, n. sp.

Allied to P. fulvigera from the Philippines, but larger, with the tegmina longer, the whole of the spots crossing the coriaceous area testaceous, those crossing its apex smaller; the blackish transverse spots considerably smaller; wings longer, the subapical transverse fulvous fasciole replaced by three or 